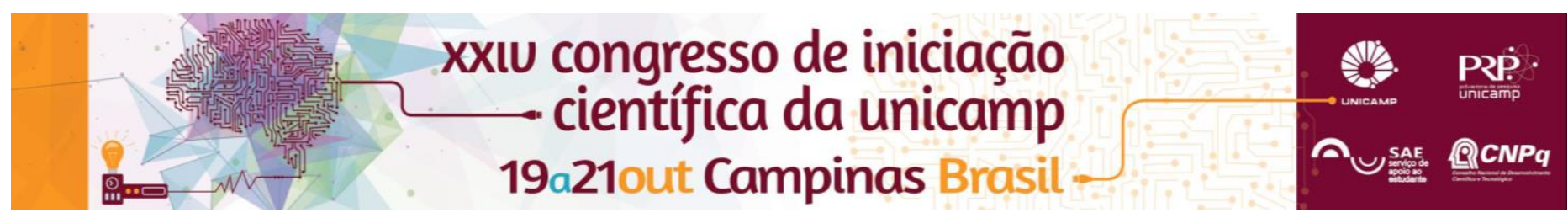

\title{
Structural observation of the epididymis after dose dependent Isotretinoin treatment of juvenile Wistar rats
}

\author{
Amanda B. Pexe*, Bruna F. Thomazini e Mary Anne H. Dolder
}

\begin{abstract}
Isotretinoin is a synthetic compound similar to vitamin A, widely used in dermatological treatments for severe acne. This compound can be considered a potentially harmful factor for the male reproductive tract causing structural changes because it is directly related to cell proliferation and differentiation. Considering the lack of information about this effect our study was directed to evaluate the epididymis structure with light microscopy associated to findings about isotretinoin use and potentially affected organs.
\end{abstract}

\section{Key words:}

Isotretinoin, epididymis, male infertility.

\section{Introduction}

Isotretinoin, or 13-cis-retinoic acid contributes to the improvement of severe acne, currently the most common dermatological desease. This substance belongs to the class of retinoids, or vitamin $A$, having biological properties similar to the vitamin ${ }^{1}$ such as cell proliferation and differentiation during fetal development and later in life ${ }^{2}$.

The male reproductive system is very sensitive to environmental conditions and to the use of medicines ${ }^{3}$, so isotretinoin may be considered a possible factor for injury which may result in temporary or permanent infertility of the patient. Therefore, this study inquired about the effects of this retinoid, assessing toxicity and epididymis structure in juvenile Wistar male rats, adding information on the safety of the drug on parameters of young male Wistar rats.

\section{Results and Discussion}

The results obtained in this study refer to the evaluation of the two epididymis regions, head and tail. 24 male Wistar rats were divided into 4 groups and the treatment included daily gavage during 60 days of water $(C)$, soybean oil (D0), $1 \mathrm{mg} / \mathrm{kg}$ of isotretioin (D1) and $10 \mathrm{mg} / \mathrm{kg}$ of isotretinoin (D10). For the analysis, we used morphometry of 30 cross sections of epididymal tubules with an approximately circular profile.

In the head of the epididymis, a possible increase in thickness of the epithelium can be observed when compared to D10. Since the drug is related to cell proliferation and differentiation ${ }^{2}$, this result was not according to the expected result. The tubular diameter was not altered in this portion. In the tail, on the other hand, no alteration could be observed. We admit the hypothesis that the epididymis head may be more susceptible to the use of this substance.
Table 1. Epidydimis tubular diameter and epithelium thickness of male Wistar rat after 60 days of treatment with isotretinoin

\begin{tabular}{|l|l|l|l|l|}
\hline Group & \multicolumn{2}{|c|}{ Head } & \multicolumn{2}{c|}{ Tail } \\
\hline & $\begin{array}{l}\text { Tubular } \\
\text { Diameter } \\
(\mu \mathrm{m})\end{array}$ & $\begin{array}{l}\text { Epithelium } \\
\text { Thickness } \\
(\mu \mathrm{m})\end{array}$ & $\begin{array}{l}\text { Tubular } \\
\text { Diameter } \\
(\mu \mathrm{m})\end{array}$ & $\begin{array}{l}\text { Epithelium } \\
\text { Thickness } \\
(\mu \mathrm{m})\end{array}$ \\
\hline C & $354,8 \pm 28,5^{\mathrm{a}}$ & $29,2 \pm 3,8^{\mathrm{a}}$ & $\begin{array}{l}450,4 \pm 36,2 \\
\mathrm{a}\end{array}$ & $26,2 \pm 2,9^{\mathrm{a}}$ \\
\hline D0 & $353,9 \pm 37^{\mathrm{ab}}$ & $34,4 \pm 3,7^{\mathrm{a}}$ & $466,5 \pm 75^{\mathrm{a}}$ & $25 \pm 3,7^{\mathrm{a}}$ \\
\hline D1 & $374 \pm 58,7^{\mathrm{ab}}$ & $31,1 \pm 4,7^{\mathrm{a}}$ & $418,6 \pm 70^{\mathrm{a}}$ & $27,1 \pm 3,17^{\mathrm{a}}$ \\
\hline D10 & $348,8 \pm 43,1^{\mathrm{b}}$ & $36,6 \pm 6^{\mathrm{a}}$ & $438,8 \pm 48^{\mathrm{a}}$ & $27,1 \pm 1,6^{\mathrm{a}}$ \\
\hline
\end{tabular}

Mean \pm standard deviation. Averages in the same column with the same letter do not differ by Kruskal-Wallis test at the $5 \%$ significance level. Group C: control with water; D0: control with soybean oil; D1: 1 $\mathrm{mg} / \mathrm{kg}$ isotretinoin; D10: $10 \mathrm{mg} / \mathrm{kg}$ of isotretinoin

\section{Conclusions}

Alteration of the head and lack of modifications in the tail were defined. This indicates that the epidydimis head is more susceptible of isotretinoin treatment in relation to the tail. Others analyses are in couse in our group to complete this work.

\section{Acknowledgement}

This work was supported by CNPq, CAPES and FAPESP.

${ }^{1}$ KOCHHAR, D.M.; CHRISTIAN, M.S. Tretinoin: a review of the nonclinical development toxicology experience. J. Am. Acad. Dermatol., St. Louis, MO, v. 36, n.3, Supl. 1, p. S47-S59, Mar. 1997.

2 SPORN, M. B, ROBERTS, A. B. What is a retinoid? In: Retinoids differentiation and disease. Ciba Found Symp.v.113, p. 1-5, 1985.

3 PANNOCHIA, M.A et al, Estratégia efetiva de fixação do testículo de ratos Wistar para avaliar os parâmetros morfológicos e morfométricos do epitélio seminífero. ConScientiae Saúde, 7(2): 227-233

4 GOULART, A. C. Efeitos do Roacutan® (Isotretinoína) sobre o aparelho reprodutor de Ratos Wistar adultos. 2013. 63 f. Dissertação (Mestrado em biologia animal) Universidade Federal de Viçosa, Minas Gerais, 2013. 